\title{
Impact of Withdrawal State Parties in 1998 Rome Statute of the Existence of International Criminal Court
}

\author{
Sandy Kurnia Christmas* \\ Faculty of Law Universitas Diponegoro, Semarang, 50275, Indoneia \\ *Corresponding author's e-mail : ch.sandykurnia@gmail.com
}

\begin{tabular}{|c|c|}
\hline ARTICLE INFO & ABStRACT \\
\hline $\begin{array}{l}\text { Keywords: } \\
\text { International Criminal Court; } 1998 \\
\text { Rome Statute; Withdrawal; State } \\
\text { Parties; International Treaty } \\
\text { How To Cite: } \\
\text { Christmas, S.K., (2017). Impact of } \\
\text { Withdrawal State Parties in } 1998 \text { Rome } \\
\text { Statute of the Existence of International } \\
\text { Criminal Court. Nagari Law Review, } \\
\text { 4(1), 28-37. } \\
\text { DOI: } \\
\text { 10.25077/nalrev.v.4.i.1.p.28-37.2020 }\end{array}$ & $\begin{array}{l}\text { The International Criminal Court is an international criminal justice institution } \\
\text { established in the context of struggle against impunity. Eighteen years of operation } \\
\text { of the ICC since 2002, ICC experienced a case where the state it one by one } \\
\text { withdraw from membership, such as South Africa, Burundi, Gambia and the } \\
\text { Philippines, which is due to the inclusion of ICC investigations related to these } \\
\text { state as well as several reasons related to the existence of discriminatory ICC } \\
\text { judicial operations patterns. What is the implementation of ICC legal norms by } \\
\text { state parties, and how the impact on the existence of ICC is what will be discussed } \\
\text { in this study. The research method used is Socio-Legal Research, which examines } \\
\text { the relationship between juridical and political aspects. The results of this study } \\
\text { conclude some evidence related to the implementation of ICC legal norms by } \\
\text { withdrawing party states, such as the background to ratifying the Rome Statute } \\
\text { 1998, the implementation of the law, and the reasons for withdrawing the country, } \\
\text { as well as some juridical and political impacts affecting the existence of the ICC. } \\
\text { C2020 NALREV. Faculty of Law Universitas Andalas }\end{array}$ \\
\hline
\end{tabular}

\section{Introduction}

International Criminal Court is an international permanent judicial institution established by the United Nations as a body that functions to try or punish perpetrators of criminal or international crimes under the Rome Statute of 1998. ${ }^{1}$ ICC jurisdiction is based on Article 5 of the Rome Statute of 1998 such as genocide crimes, war crimes, crimes against humanity and crimes of aggression. ${ }^{2}$ During the 18 years of operation since its entry into force in 2002, the ICC has experienced cases by several state parties, such as South Africa, Burundi, Gambia and the Philippines who chose to withdraw from ICC membership because they have always been the target of investigations, as well as a perceived bias towards ICC that is biased and discriminatory in carrying out his judicial operations.

Cases that occur in South Africa, Gambia and Burundi because the ICC is too partial to corner the countries in Africa against Africa and its leaders, and there are reasons that interfere with the government's role in resolving conflicts peacefully. ${ }^{3}$ The African withdrawal arises because of concerns over the ICC trying to try some of the leaders in Africa as well as threats from the ICC for not arresting Sudanese President Omar Al-Bashir who was accused of genocide and role crimes. This is compounded by the notion that the ICC failed in trying the European Union (EU) for the deaths of thousands of African migrants trying to reach the European coastline.

Anis Widyawati. (2014). Hukum Pidana Internasional. Jakarta : Sinar Grafika, p.150.

Laura Bernett. (2018). “The International Criminal Court : History and Role”. Library of Parliament, 2002(11) : 1-28.

Mathole Serofo Mortheskga. (2017). South Africa Should Not Withdraw from the International Criminal Court. Swiss :

International Commission of Jurist, p.3. 
The case that occurred in the Philippines related to the existence of an ICC examination for alleged illegal killings in an effort to eradicate drugs by Philippine President Rodrigo Duterte. The action of the President of the Philippines is claimed for alleged crimes against humanity by carrying out extrajudicial killings in the context of eradicating drugs. The protest issued by the President of the Philippines considers it a policy that does not violate humanity or genocide.

The ICC as an international judiciary in this respect respects any decision of countries to withdraw from the membership of the ICC based on Article 127 of the 1998 Rome Statute. Based on these problems, withdrawal may be possible to impact on its implementation in law enforcement which is not effective. According to some international law experts, the ICC, which was formed based on the Rome Statute of 1998, has a strong and strong substance, but is weak in its implementation. ${ }^{4}$ It is recognized that there are obstacles in the implementation of law enforcement that still implements the dominant political practices of the World War II winning countries, so that the applied justice is "Victory Justice". The existence of dominant political practices leads to various kinds of bad intentions of countries due to differences in political interests.

Based on these problems in his understanding related to the withdrawal of a state party from the ICC, the author would like to develop a journal entitled, "The Impact of Withdrawal State Parties in Rome Statute 1998 of the Existence of the International Criminal Court". The problems of this research are: (1) What is the implementing of International Criminal Court legal norms by State Parties who withdrew from the 1998 Rome Statute ?; and (2) What is the impact of the withdrawal of State Parties from the 1998 Rome Statute on the existence of the International Criminal Court?

Research related to the impact of a country's withdrawal from international treaties and discussion of the ICC has never been done before. Research by Daniel Aditia Situngkir discusses the existence of state sovereignty in the application of ICC jurisdiction. ${ }^{5}$ In research related to ICC jurisdiction by Michael P. Scharf discusses the ICC Jurisdiction on the position of non-party countries in the 1998 Rome Statute. ${ }^{6}$ The research by Max Du Plesis, Tiyanjana Maluwa, and Annie O'Rellie discusses the basic criticism of Africa Union regarding discriminatory ICC investigative patterns. ${ }^{7}$ Research by Rowland Cole discusses Africa's relationship with the ICC, which considers the ICC to be more a political institution than a legal institution. ${ }^{8}$ The research on the withdrawal of ICC participating countries by Manisuli Ssenyonjo discusses the reasons and impacts of withdrawals experienced by the ICC in general, while in scientific research this study discusses more fully the juridical and political impacts faced by the ICC and a state party due to withdrawal using legal theories. ${ }^{9}$

\section{Method}

The discussion on the impact of state party withdrawal on the existence of the ICC was examined using a study of the Socio-Legal Approach method in relation to the relationship between legal and political aspects, as well as the study of this research using the legislative approach, case approach, historical approach, and social approach.

4 Michael Struett. (2004). “The Meaning of International Criminal Court”. Peace Review, 16(3): 317-321.

5 Danel Aditia Situngkir. (2018). “Eksistensi Kedaulatan Negara Dalam Penerapan Yurisdiksi Mahkamah Pidana Internasional". Jurnal Ilmu Hukum Lex Librum, 4(2): 659-672.

6 Michael P.Scharf. (2001). "The ICC's Jurisdiction Over the Nationals of Non-Party State : A Critique of the U.S. Position”. Law and Contemporary Problems, 64(1): 67-117.

7 Max Du Plesis, Tiyanjana Maluwa, \& Annie O’Reilly. (2013). “Africa an the International Criminal Court”. Chatham House International Law, 1(1): 1-13.

8 Rowland J.V. Cole. (2013). "Africa's Relationship With The International Criminal Court : More Political Than Legal". Melbourne Journal of International Law, 14 : 670-698.

9 Manisuli Ssenyonjo. (2017). "State Withdrawal Notification from The Rome Statute of the Statute of International Criminal Court". Journal of Criminal Law Forum. 29(1) : 63-119. 
In this socio-legal study, secondary data are used as binding force in it which consists of binding primary legal materials such as the Rome Statute of International Criminal Court, the Vienna Convention of the Law of Treaties 1969, and the UN Charter. And examined using secondary legal material in books, articles, journals, and papers that are relevant in research.

\section{Analysis or Results}

\subsection{Impementing International Criminal Court Legal Norms by State Parties}

The International Criminal Court is an international criminal justice institution formed based on mutual agreement in the Rome Conference of 17 July 1998 which produced the 1998 Rome Statute which aims to prevent crimes that endanger world security and peace. ${ }^{10}$ The legal basis for the entry into force of the 1998 Rome Statute is based on Article 126, whereby the 1998 Rome Statute can take effect after the receipt of the instruments of ratification by 60 countries and after the signing, the statute must be ratified and accepted by the countries. The act of ratification of the 1998 Rome Statute reflects an implementation of ICC legal norms by state parties. Based on the theory of monism, the formation of the 1998 Rome Statute as an international treaty was the joint will of countries. ${ }^{11}$ The ICC has the authority to adjudicate justice for an act of crime if the country is unwiling or unable to enforce the law against crime. ${ }^{12}$

According to Hans Kelsen, legal norms are rules, patterns, or standards that need to be followed.13 The legal norm basically looks at how a rule or law determines behavior and attitude in society. The legal norm is considered functioning when it can protect the interests of society in general, so that the purpose of the legal norm is to create peace and order in the community. Countries which have ratified the 1998 Rome Statute agreed to prosecute the perpetrators accused of committing these legal crimes for peace and security, this is not like the previous tribunal court which was not retroactive. ${ }^{14}$

Regarding the implementation of ICC legal norms by state parties, several cases against the state have problems in implementing the ICC legal norms so that it has an impact on withdrawal. The problem in implementing this law is due to the emergence of several cases of investigations carried out by the ICC, so that according to some countries the investigation has a detrimental impact on the country. Procedures for withdrawal from the Rome Statute are regulated in Article 127 of the 1998 Rome Statute.

The implementation of the legal norms of the ICC by South Africa is based on South Africa's opinion of the ICC as an institution that can provide penalties for perpetrators of international crimes, which so far South Africa has always been discriminated against, thus ratifying the 1998 Rome Statute on 27 November 2000. The process of implementing the Statute Rome 1998 in South Africa was issued by "The Implementation of the Rome Statute of the International Criminal Court Act 17 of 2002" which contained a framework for the application of the jurisdiction of the Rome Statute of 1998 (Dugard, 2000). ${ }^{15}$

10 Rahim Arhjayati. (2017). “Urgensi Ratifikasi Statuta Roma Wujud Eksistensi Mahkamah Pidana Internasional (International Criminal Court) dalam Penyelesaian Kasus pelanggaran HAM". Jurnal Al-Himayah, 1(1): 1-24.

11 Bruno Simma. (1995). "The Contribution of Alfred Verdross to the Theory of International Law", European Journal of International Law, 6(1): 33-54.

12 Made Putri Saraswati \& AA.Gede Oka Parwata. (2014). “Penerapan Asas Ne Bis In Idem Dalam Hukum Pidana Internasional". Jurnal Kertha Negara, 2(4): 1-5.

13 Yuliandri. (2009). Asas-Asas Pembentukan Peraturan Perundang-Undangan Yang Baik. Jakarta : PT.Raja Grafisindo Persada, p.21.

14 Christiane E. Philipp. (2003), “The International Criminal Court - A Brief Introduction”. Journal od Max Planck Institute for European Legal History, 7:331-339.

15 John Dugard. (2000). International Law : A South African Perspective (2 ${ }^{\text {nd }}$ Edition). Juta : Lansdowne, p.142. 
South Africa's withdrawal from the ICC is due to the emergence of investigations into Sudan, which traced 1.65 million displaced people and more than 200,000 people displaced from Darfur to Chad. Departing from the situation in Sudan for the first time the ICC conducted an investigation into a nonparty state of the Rome Statute. South Africa disputed and criticized the arrest warrant issued by the ICC and rejected the arrest because of the capacity of the President of Sudan as a diplomatic guest to attend the African Union Summit in Johannesburg.

According to the South African government, the ICC must pay attention to the process of surrendering the President of Sudan in accordance with Article 98 of the 1998 Rome Statute on Cooperation Regarding the exclusion of Immunity and Consent for Submission. The ICC cannot proceed with requests for surrender and assistance that require countries to act inconsistently with their obligations, unless the ICC obtains cooperation from a third country.

The implementing the ICC legal norms in Burundi is evidenced by the ratification of the 1998 Rome Statute. Burundi has suffered nearly five years due to genocide and attacks by terrorist groups on innocent people in Burundi, so he requested that an international Ad Hoc criminal court be formed in Burundi to help national reconciliation of cases in his country. The implementation of the Rome Statute of 1998 by Burundi is contained in Articles 274-227 of The Constitution of Burundi's 2005, which is an organic law that determines the mission, composition, organization and functioning of the "National Observatory" for the prevention and eradication of genocide, war crimes and crimes against humanity.

Burundi's withdrawal is based on the inclusion of an ICC investigation into crime that recorded 1,200 murders, thousands of people were illegally detained and tortured, and hundreds of people have disappeared since 2015 in Burundi. During the investigation, the OTP collected evidence of crimes against humanity that occurred inside and outside Burundi by its citizens from 26 April 2015 to 26 October 2017.16

The implementation of ICC legal norms by the Gambian is based on the uncertainty of the previous Gambian government in its struggle against impunity. After the election of new president Adama Barrow, the Gambia opened opportunities to strengthen the rule of law in Gambia by ratifying the 1998 Rome Statute on June 28, 2002. Despite being one of the countries that had ratified the 1998 Rome Statute, until now the Gambia has not implemented the 1998 Rome Statute into law implementing regulations or laws relating to cooperation with the ICC.

Less than a week after South Africa announced its withdrawal from the ICC, the Gambia made a withdrawal on October 25, 2016 for the appointment of selective prosecutions of Africans. This was expressed and considers the ICC persecuting Africans, especially their leaders, but turning a blind eye to crimes committed against western countries. Through his statement, at least thirty Western countries have been named for war crimes against sovereign states and their citizens, but have never been examined by the ICCFor example, the ICC was not successful in conducting an investigation into the deaths of 2000 migrants and 800 African refugees who died from shipwrecks in European regions to hold the EU accountable for the case. The Gambian concern is not only in cases involving African countries, but also concerns that President Jammeh has the potential to become the target of an ICC investigation that took power in a 1994 coup, and committed serious crimes during his leadership, such as: enforced disappearances ; arbitrary arrest and detention; torture.

The last country, the Philippines, was one of the countries in the Asian region which ratified the Rome Statute of 1998 on August 30, 2011. The signing was considered as its support of the ICC as the first institution that has the power to exercise jurisdiction over people for the most serious crimes of

16 International Criminal Court. (2019). Situation in Republic of Burundi (ICC-01/17). Available online from : https://www.icccpi.int/burundi. [Accessed November 14, 2019]. 
international concern. The Philippines implemented the 1998 Rome Statute into national law in Republic Act No.9851 - Act Defining and Penalizing Crimes Against International Humanitarian Law, Genocide and Other Crimes Against Humanity, Organizing Jurisdiction, Designating Special Courts, and for Related Purpose.

Philippine membership in the ICC did not last long. The Philippines was forced to withdraw from the ratification of the 1998 Rome Statute on March 17, 2018 due to the entry of an ICC investigation into the Philippines in 2016 on the grounds of murder related to alleged involvement of people in drug use or trafficking. Allegations of murder have been reported because they involved extrajudicial killings in the context of anti-drug operations. Duterte tried to avoid international oversight of drugs, and continued to carry out its policies in combating drug trafficking.

The implementing the ICC legal norms by the four countries that withdrew was based on the rule of law and law enforcement officers. The purpose of analyzing the legal norms of the ICC by these state parties is to see the existence of social stability, security, justice, order and order applied by the ICC in the 1998 Rome Statute of the withdrawing state parties.

\subsection{Impact of State Parties Withdrawal on the Existence of International Criminal Court}

The withdrawal of the countries of South Africa, Burundi, Gambia, and the Philippines from the ICC is a legal attempt by the country to break away from the boundaries of the 1998 Rome Statute. The withdrawal of a country from the 1998 Rome Statute is a question mark for that country, because it does not immediately considered to have frustrated the intent and purpose of the 1998 Rome Statute.

The withdrawal was actually indicated to avoid the ICC's responsibility for international crimes. However, based on Article 127 paragraph (2) of the 1998 Rome Statute concerning Withdrawal, a country that withdraws from the 1998 Rome Statute cannot influence its cooperation in connection with investigations and criminal proceedings that are taking place. This is because investigations into crimes committed before withdrawal are based on temporal jurisdiction (Article 11) as a force of jurisdiction. ${ }^{17}$

In general, the reasons for withdrawal are related to the loss of ICC credibility due to the politicization of the UNSC; application of double standards to ICC investigations; as well as conflicts with international legal obligations relating to the right to immunity. The loss of ICC credibility due to the politicization of the UNSC due to the veto of the UNSC is the reason that the position of this body is limited to political interests. This is because 3 out of 5 permanent members of the UN Security Council did not participate in the Rome Statute, making it vulnerable to decisions that would not be on their side or their allies could be vetoed. For example, the United States used its veto rights as a reference for investigating crimes committed by US military forces to the situation in Afghanistan in 2003-2004 for war crimes, torture, and inhuman treatment.

The existence of the application of double standards by the ICC is related to the implementation of rapid application of crimes committed by the west, but slow in handling cases related to allied countries. Of the 12 cases that were included in the ICC investigation, only 2 cases were not from Africa. The 10 cases that were referred by the states or through the UN Security Council were from Africa. This is a question as to why the ICC has always focused on Africa. On that basis, African countries feel discriminated against which results in their heads of state some of whom are targeted by the ICC investigation.

17 Olivia. (2017). “Kewenangan ICC (International Criminal Court) Dalam Melakukan Penegakan Hukum terhadap Kejahatan Kemanusiaan". Lex Privatum, 5(8): 94-101. 
In fact, for some cases that have been proven to be carried out by the state, such as the United States which clearly sends its military forces to a country and conduct military operations in that country, it has been proven to enter into an act of aggression (Article 8 bis). Add to this the case that Africa had referred to over the sinking of ships carrying African immigrants to Europe in the Mediterranean. The immigrants are thought to have fled Libya, where as many as 6,000 immigrants from Eritrea, Ethiopia, Somalia and other countries have been locked up in Libyan detention facilities. The sinking was allegedly related to efforts to stop dangerous sea crossings by Europeans. Until now the case of the sinking of the immigrant ship has not been investigated.

The third reason is the conflict between international legal obligations with the 1998 Rome Statute regarding the right to immunity. The establishment of the 1998 Rome Statute and the ICC aims to uphold human rights for serious crimes contained in the jurisdiction of the ICC as well as a form against immunity. This form of resistance to immunity was interpreted by the 1998 Rome Statute to force state parties to arrest people who are enjoying diplomatic immunity under international law. This contradicts the international legal obligations related to the right of diplomatic immunity / immunity regulated in the 1961 Geneva Convention on Diplomatic Relations, because it causes a Head of State to be referred to a court without being able to defend himself using his immunity rights. This case happened to President Al Bashir of Sudan who is not a member country.

Regarding the abolition of the right to immunity under Article 27, it only applies to state officials who are parties to the 1998 Rome Statute, and not to non-state parties. This is due to the principle of Pacta Sunt Servanda where the agreement is binding on the state that is bound to the agreement that has been made. ${ }^{18}$

Based on the reasons for withdrawal, according to the Theory of Legal Work in the Community, there must be a balance between regulatory institutions, regulatory / sanctioning institutions, and role occupants, ${ }^{19}$ but it is unfortunate that the balance of legal work in institutions This international criminal court is disrupted because of the treatment of implementing institutions / regulations that seem discriminatory that apply double standards and the use of veto by the UNSC which seems only for political purposes. So this has an impact on countries as role holders in complying with the rule of law in the 1998 Rome Statute.

Based on the theory of the operation of law in the community, each section basically must have a role in efforts to realize the aims and objectives of the law, and these efforts must have feedback on the basis of reciprocity principles in international treaties. This means that an international agreement of a country against another country can be repaid in kind. ${ }^{20}$

Reciprocity for its support of the ICC can also be in the form of collaboration to help handle cases that are investigated by the ICC. But it is this failure to cooperate that is the reciprocal constraint that does not work effectively. This is because the ICC has never responded to reports sent by these countries (especially Africa) to the ICC, so on that basis countries respond to their mutual relations with the ICC only to the extent of reciprocity that does not have a positive impact on them.

Even though the State Party which withdrew in this regard had implemented the Rome Statute in 1998 well, its decision not to cooperate with the ICC basically violated the principles of international law in the principle of Pacta Sunt Servanda where the agreement was binding and had to be carried out in

18 Syaeful Bahri \& Jawade Hafidz. (2017). “Penerapan Asas Pacta Sunt Servanda Pada Testament Yang Dibuat Di hadapan Notaris Dalam Perspektif Keadilan". Jurnal Akta, 4(2) : 152-157.

19 Bambang Santoso. (2007). "Relevansi Pemikiran Teori Robert B.Seidman Tentang 'The Law of Non Transferability of The Law' Dengan Upaya Pembangunan Hukum Nasional Indonesia". Jurnal Yustisia, 70: 1-8.

20 Ni Made Adinda Wikan Dewi. (2018). "Penerapan Asas Manfaat dan Asas Timbal Balik Dalam Perpres RI No.21 Tahun 2016 Tentang Bebas Visa Kunjungan". Jurnal Kertha Negara, 6(4): 1-13. 
good faith. The cooperation between countries that withdraw from the ICC cannot be implemented based on discriminatory ICC treatment, so they refuse to cooperate.

According to the Theory of Working of the Law in Society emphasizes the functioning and effectiveness of law is in the balance of the three roles. The existence of injustice of the ICC as a regulatory agency that carries out its laws that are considered discriminatory by the four countries has caused a balance between the regulatory implementing agency and the stakeholders not going well. ICC as a sanctioning institution is considered to have committed acts of discrimination in carrying out its legal jurisdiction. This contradicts the definition of the implementing agency which is a strict implementing agency in carrying out the instructions contained in the legislation without discrimination (equal justice under law).

The operation of the law against the implementing agency of this regulation is seen from the strict implementation of implementing the law without discrimination, so it can be said if the ICC is not successful in implementing its law. Although in some of these countries the withdrawal was indicated as a form of avoiding responsibility for ICC investigation, but according to Article 127 of the Rome Statute in 1998 the country that withdrew could not influence its cooperation with the ICC which began before the withdrawal became effective. There are three reasons for the ineffectiveness of the law according to Anthony Allot, namely: there are limitations in expressing legal norms; there is a conflict between the objectives of the legislator and the community's response in carrying out the law; and the existence of an inadequate process of implementing legal norms against legal comission. ${ }^{21}$

Based on the analysis of the theory, it has an impact on the existence of the ICC. This impact at least affects the existence of the ICC in the future regarding whether the court is still worthy of being called an independent institution or political interest. Juridical impact on the ICC due to withdrawal is the limitations of the ICC in investigating and prosecuting future cases because they are no longer bound to the Rome Statute of 1998. The limitations of the ICC only apply to countries that have officially withdrawn, and this means they are not the entry into force of the ICC jurisdiction for that country. Article 11 of the Rome Statute of 1998 states that the ICC only has jurisdiction in connection with crimes after the entry into force of this Statute for a state party. This means that the limitations of the ICC in investigating and prosecuting cases in the future are due to the application of the temporal jurisdiction of the ICC which has no power after the withdrawal of ratification.

The next juridical impact on the ICC is the potential for crimes committed by state officials with impunity in the future because only the 1998 Rome Statute can exclude the right to immunity committed by State Officials. After the withdrawal is effective, it is not impossible that a country that is not a state party has the potential to commit a crime due to the absence of ICC jurisdiction over their country.

The political impact on the ICC is an indication of failure to cooperate with other parties. This failure can be said to be the country's non-compliance with the ICC. This happened to South Africa before withdrawing, who refused to cooperate with the ICC because it was considered to set a double standard that reflected the injustice of the court. In practice, the successful implementation of the ICC depends on state cooperation in complying with arresting and surrendering criminal offenders. So this implies that the ICC does not have the power to force state compliance with its requests (Banteka, 2016).

Politically, this withdrawal also has an impact on the reduced interest of countries that will ratify the 1998 Rome Statute. This is a consideration of countries that have not ratified the 1998 Rome Statute

21 Anthony Allot. (1981). “The Effectiveness of Laws”. Valparaiso University Law Review, 15(2): .229-242. 
because of the influence of the withdrawing country on the grounds that the ICC applies its legal system which only based on political interests. The diminished interest of countries in the 1998 Rome Statute was also due to their fear of the jurisdiction applied by the ICC that could intervene in the country's sovereignty. ${ }^{22}$ Because basically, the concept of sovereignty becomes a characteristic in international relations and relations between nations, which is the reason that sovereignty will create a bond in international law. ${ }^{23}$ An example of a country that originally wanted to join the ICC but was canceled was Malaysia on 5 April 2019, due to the opposition politicization that took place in Malaysia which raised concerns that if Malaysia continued to ratify the 1998 Rome Statute it would become the next ICC's investigation target. This is considered to be able to trigger intervention by the ICC, although in international law prohibited the intervention measures for interference in domestic affairs and threatened state sovereignty. ${ }^{24}$

Related to this withdrawal also has an impact on State Parties, although this withdrawal has no impact on ICC cooperation, but legally for the country there are at least a number of impacts that occur such as: the inactivity of the ICC's jurisdiction after effective withdrawal takes effect. This is related to the loss of a country's attachment to international treaties, which legally the jurisdiction of the ICC is limited to the territory of a State Party in accordance with the legal status and power of the court in Article 4 paragraph (2) of the Rome Statute of 1998. The release of a country's attachment from the ICC can also indicate the implementation of the law implementing the 1998 Rome Statute may be revoked; and no legal obligations to the ICC after effective withdrawal takes effect.

\section{Conclusion}

Withdrawal of an international treaty is an action to break away from the treaty, so that the jurisdiction of the international treaty no longer applies to that country. In the case of the withdrawal of South Africa, Burundi, Gambia and the Philippines, which became state parties, then withdrew from the 1998 Rome Statute, raising questions about the concept of protection and actual enforcement of human rights, because the ICC is considered an international institution representing countries to be able to provide protection and enforcement of human rights.

The operation of the law at the ICC must be based on reciprocal responses to legal regulations, institutions, and role holders. The lack of response and reciprocity between the ICC as a sanctioning institution and the country withdrawing as the holder of the role makes the legal balance not run well. According to Seidman in the theory of the operation of law in the community, for state parties as the role holder what the desired role holder has in return to the sanctioning implementing agency is the fair use of law against all countries, this implies that these functions must operate without discrimination. The position of the ICC as a sanctioning implementing agency should be able to provide solutions for other countries because the ICC is considered to have legal power. The impact of withdrawal basically implies criticism of the legal system run by the ICC.

Based on this research, the existence of evidence related to the operation of the legal system applied by the ICC so that the impact on the withdrawal of several state parties should not occur again. ICC is expected to be able to become a permanent international justice institution and be able to maintain its independence as the only permanent judicial institution that is specialized in cracking down on perpetrators of serious crimes, and able to bring about justice for the international community. This

22 Cenap Cakmak. (2006). “The International Criminal Court in World Politics”, International Journal on World Peace, 23(1): 340.

23 Sandy Kurnia Christmas \& Evi Purwanti. (2020). "Perkembangan Sistem Pemerintahan dan Konsep Kedaulatan Pasca Revolusi Perancis Terhadap Hukum Internasional. Jurnal Pembangunan Hukum Indonesia, 2(2): 222-235.

24 Sandy Kurnia Christmas \& Joko Setiyono. (2019). "Intervensi Militer Terhadap Kudeta Politik Menurut Prinsip Jus Cogens". Jurnal Pembangunan Hukum Indonesia, 1(3): 308-321. 
independence is needed to maintain the dignity of this institution so that it can carry out its objectives in breaking the chain of impunity to be realized.

For state parties, especially for countries that are still members of the ICC are related to the pattern of their cooperative relations with the ICC in conducting investigations. The State Parties are expected to be able to carry out their obligations according to the rights and obligations they are responsible after ratifying the 1998 Rome Statute. The collaboration is expected to be based on the principles of international treaty law.

\section{References}

Books

John Dugard. (2000). International Law : A South African Perspective (2nd editio). Juta: Lansdowne.

Motshekga, M. S. (2017). South Africa Should Not Withdraw from the International Criminal Court. In International Commission of Jurist. Swiss: International Commission of Jurist.

Widyawati, A. (2014). Hukum Pidana Internasional. Jakarta: Sinar Grafika.

Yuliandri. (2009). Asas-Asas Pembentukan Peraturan Perundang-Undangan Yang Baik. Jakarta: PT. Raja Grafindo Persada.

\section{Journal}

Anthony Allot. (1981). “The Effecteviness of Laws”. Valparaiso University Law Review, 15(2): .229-242.

Bambang Santoso. (2007). "Relevansi Pemikiran Teori Robert B.Seidman Tentang 'The Law of Non Transferability of The Law' Dengan Upaya Pembangunan Hukum Nasional Indonesia". Jurnal Yustisia, 70: 1-8.

Bruno Simma. (1995). "The Contribution of Alfred Verdross to the Theory of International Law", European Journal of International Law, 6(1): 33-54.

Christiane E. Philipp. (2003), "The International Criminal Court - A Brief Introduction”. Journal od Max Planck Institute for European Legal History, 7:331-339.

Cenap Cakmak. (2006). “The International Criminal Court in World Politics”, International Journal on World Peace, 23(1): 3-40.

Danel Aditia Situngkir. (2018). “Eksistensi Kedaulatan Negara Dalam Penerapan Yurisdiksi Mahkamah Pidana Internasional". Jurnal Ilmu Hukum Lex Librum, 4(2): 659-672.

Laura Bernett. (2018). "The International Criminal Court : History and Role". Library of Parliament, 2002(11) : 1-28.

Made Putri Saraswati \& AA.Gede Oka Parwata. (2014). "Penerapan Asas Ne Bis In Idem Dalam Hukum Pidana Internasional". Jurnal Kertha Negara, 2(4): 1-5.

Manisuli Ssenyonjo. (2017). “State Withdrawal Notification from The Rome Statute of the Statute of International Criminal Court". Journal of Criminal Law Forum. 29(1) : 63-119. 
Max Du Plesis, Tiyanjana Maluwa, \& Annie O’Reilly. (2013). “Africa an the International Criminal Court". Chatham House International Law, 1(1): 1-13.

Michael Struett. (2004). “The Meaning of International Criminal Court”. Peace Review, 16(3): 317-321.

Michael P.Scharf. (2001). “The ICC's Jurisdiction Over the Nationals of Non-Party State: A Critique of the U.S. Position". Law and Contemporary Problems, 64(1): 67-117.

Ni Made Adinda Wikan Dewi. (2018). “Penerapan Asas Manfaat dan Asas Timbal Balik Dalam Perpres RI No.21 Tahun 2016 Tentang Bebas Visa Kunjungan". Jurnal Kertha Negara, 6(4): 1-13.

Olivia. (2017). “Kewenangan ICC (International Criminal Court) Dalam Melakukan Penegakan Hukum terhadap Kejahatan Kemanusiaan”. Lex Privatum, 5(8): 94-101.

Rahim Arhjayati. (2017). “Urgensi Ratifikasi Statuta Roma Wujud Eksistensi Mahkamah Pidana Internasional (International Criminal Court) dalam Penyelesaian Kasus pelanggaran HAM". Jurnal Al-Himayah, 1(1): 1-24.

Rowland J.V. Cole. (2013). “Africa's Relationship With The International Criminal Court : More Political Than Legal". Melbourne Journal of International Law, 14 : 670-698.

Sandy Kurnia Christmas \& Evi Purwanti. (2020). “Perkembangan Sistem Pemerintahan dan Konsep Kedaulatan Pasca Revolusi Perancis Terhadap Hukum Internasional. Jurnal Pembangunan Hukum Indonesia, 2(2): 222-235.

Sandy Kurnia Christmas \& Joko Setiyono. (2019). “Intervensi Militer Terhadap Kudeta Politik Menurut Prinsip Jus Cogens". Jurnal Pembangunan Hukum Indonesia, 1(3): 308-321.

Syaeful Bahri \& Jawade Hafidz. (2017). “Penerapan Asas Pacta Sunt Servanda Pada Testament Yang Dibuat Di hadapan Notaris Dalam Perspektif Keadilan". Jurnal Akta, 4(2) : 152-157.

\section{Online Resources}

International Criminal Court. (2019). Situation in Republic of Burundi (ICC-01/17). Available online from : https://www.icc-cpi.int/burundi. [Accessed November 14, 2019]. 